УДК 004.93:004.4'2:004.382.75

๑ Ю. В. Ратушняк, аспірант, УАД, Львів, Україна

\title{
МЕТОД РОЗРОБЛЕННЯ КОНЦЕПТУАЛЬНИХ ПРОТОТИПІВ ЕЛЕКТРОННИХ ВИДАНЬ ДЛЯ ПЛАНШЕТНИХ КОМП'ЮТЕРІВ
}

У процесі проектування електронних видань для планшетних комп'ютерів використовують різноманітні методи й апаратно-програмні засоби розроблення прототипів. Дослідження та створення нових ефективних методів отримання концептуальних прототипів електронних видань для планшетних комп'ютерів є актуальним і доцільним завданням. У роботі його вдалося виконати з використанням методів системного аналізу. Таким чином, проаналізовано найбільш відомі способи отримання інтерактивних структурних прототипів системи на основі ії паперових зразків. Запропоновано метод розроблення концептуальних прототипів і показано його місце у структурі інформаційної технології проектування електронних видань для планшетних комп'ютерів. Визначено перелік потенційних недоліків пропонованої автоматизованої системи проектування. Наведено приклад застосування запропонованого методу. Названо апаратно-програмне забезпечення, потрібне для розроблення автоматизованої системи проектування концептуальних прототипів електронних видань для планшетних комп'ютерів. Створено макет інтерфейсу початкового екрана автоматизованої системи проектування $\mathbf{i}$ розглянуто його компоненти.

Ключові слова: автоматизована система проектування; електронне видання; інтерфейс; інформаційна технологія; концептуальний прототип; метод; планшетний комп'ютер; проектування; розроблення.

\section{Постановка проблеми}

Інформаційна технологія проектування електронних видань (EB) для планшетних комп'ютерів (ПлК) - це процес з визначеною організаційною структурою, протягом якого група проектувальників, користувачів та всіх зацікавлених сторін використовує певну сукупність методів і засобів отримання, обробки, зберігання й передавання первинної інформації для то- го, щоб перетворити її в новий інформаційний продукт. Структура інформаційної технології проектування EВ для ПлК являє собою ієрархічно впорядкований і взаємопов'язаний набір компонентів (функціональних блоків). Кожний рівень ієрархії якої позначає основні види функцій $[1,2]$ (рис. 1).

На виходах функціональних блоків А52, А53, А54, А55 отримують попередні альтернативні 


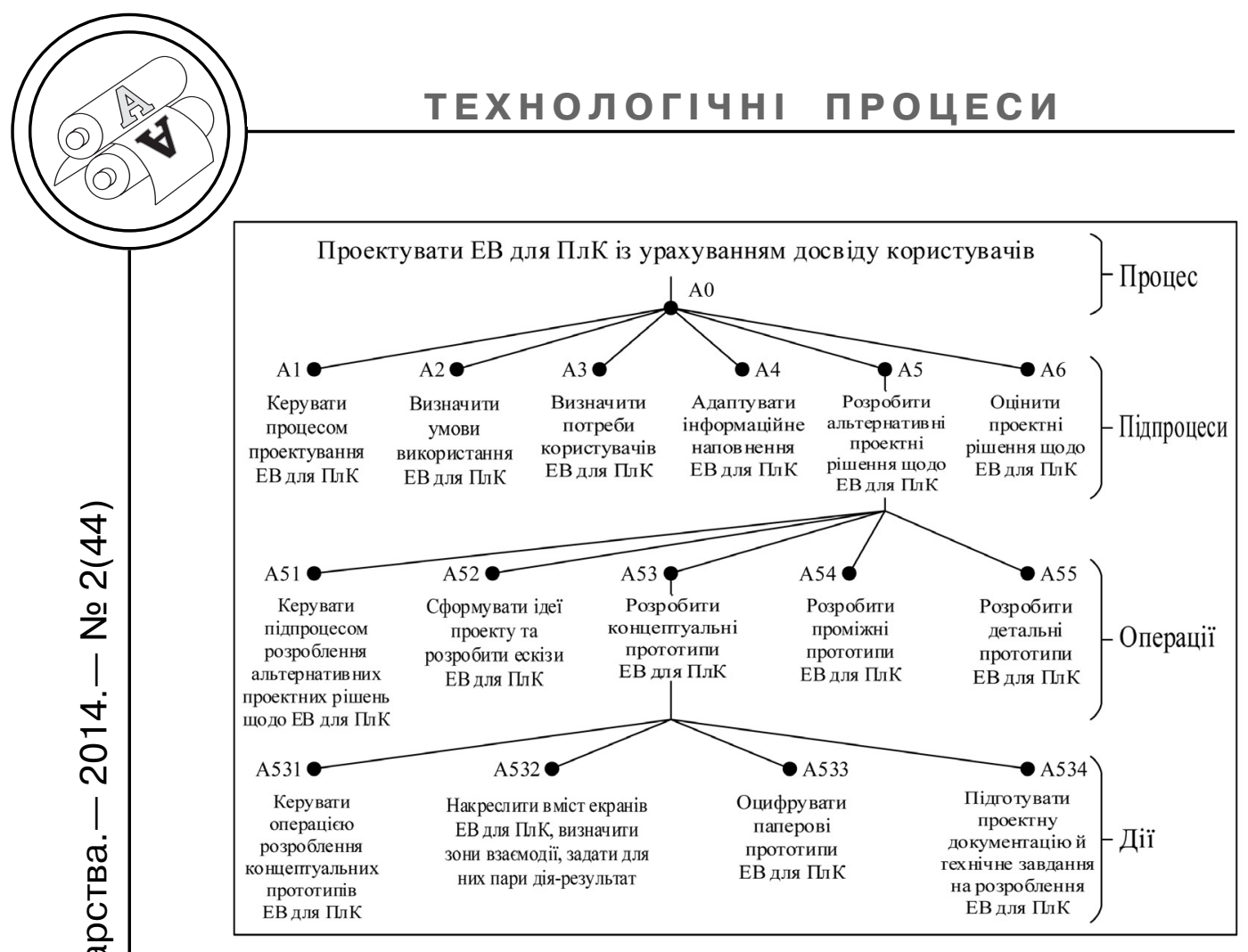

Рис. 1. Структура інформаційної технології проектування електронних видань для планшетних комп'ютерів

варіанти EB для ПлК у вигляді прототипів різного рівня складності. Зокрема, на виході блоку А53 отримують концептуальні прототипи ЕВ для ПлК і визначають можливість ї реалізації в процесі розроблення ЕВ для ПлК. Спеціалісти, які оцінюють придатність до використання прототипів ЕВ для ПлК за участі зацікавлених сторін здійснюють оцінку й порівняння альтернатив на основі розгляду розкадровок паперових прототипів ЕВ для ПлК і базових структурних інтерактивних прототипів ЕВ для ПлК. Зауважимо, що для забезпечення процесу розроблення EВ для ПлК не завжди виникає потреба в створенні всіх видів прототипів системи, що проектують (концептуальних, проміжних, детальних). Зазвичай достатньо сформованих ідей та розроблених ескізів і розкадро- вок ЕВ для ПлК, а також декількох концептуальних прототипів ЕВ для ПлК для того, щоб уточнити найважливіші й оригінальні елементи майбутнього ЕВ для ПлК. Остаточне рішення щодо кількості необхідних прототипів ЕВ для ПлК і відповідно повноти потрібної проектної документації й технічного завдання на розроблення ЕВ для ПлК приймає керівник проекту після аналізу всієї доступної інформації з даного питання.

У зв'язку з необхідністю удосконалити процес проектування $\mathrm{EB}$ для ПлК, актуальним i доцільним завданням вважаємо дослідження та створення ефективних методів отримання концептуальних прототипів ЕВ для ПлК, як обов'язкової передумови розроблення таких видань. 


\section{Аналіз попередніх досліджень}

Паперові прототипи ЕВ для ПлК - це дешевий, швидкий, зрозумілий для спеціалістів спосіб, в який можна отримати попередні зразки розроблюваної системи. На відміну від нього, робота із спеціалізованим програмним забезпеченням (наприклад, Axure RP, Balsamiq Mockups тощо) на ранніх етапах проектування системи відволікає спеціаліста від розв'язання поставленої задачі (розроблення концептуальних прототипів EВ для ПлК). Значну частину уваги проектувальник приділяє саме інструментарію прикладної програми й програмуванню прототипів (процесу), а не творчій складовій реалізації задуманого. Для розроблення прототипів різного рівня складності часто використовують не призначені для цього програмні продукти 3 надлишковими або відсутніми функціональними можливостями, що також створює додаткові труднощі для проектувальників. Наприклад, редактори векторної (Adobe Illustrator) і растрової (Adobe Photoshop) графіки, програмні пакети для опрацювання тексту (Microsoft Word), діаграм (Microsoft Visio), презентацій (Microsoft PowerPoint) тощо. Taким чином, типова процедура передбачає, що проектувальник спочатку розробляє паперові прототипи системи, після цього вручну (з допомогою АСП - автоматизованої системи проектування) переводить їх у цифрову форму, а ще пізніше, переведений у електронну форму прототип, передає розробнику, який на його основі створює ЕВ для ПлК. Такий підхід важко назвати раціональним [3].

Передусім, проаналізуємо найбільш відомі способи отримання інтерактивних структурних прототипів системи на основі іï паперових зразків. Усі відомі методи використовують ескізи як основу для створення інтерактивних прототипів системи. Деякі з них (Paper-in-Screen [4], Prototyping on Paper [5], UXPin Notepads [6], «Digital Pen» [7] тощо) розроблені для того, щоб забезпечити процес проектування інтерфейсів систем для мобільних пристроїв (смартфонів, ПлК), інші (ActiveStory [8], SILK [9], DENIM [10] тощо) потрібно адаптувати для вирішення цієї задачі. Коротко розглянемо основні недоліки відомих методів, що повинні бути враховані при створенні нового методу розроблення концептуальних прототипів ЕВ для ПлК.

Метод Paper-in-Screen. Паперові прототипи EB для ПлК у цифровій формі проходять тривалу процедуру підготовки до оцінювання. Спочатку цифрові фотознімки або скановані копії редагують, пізніше розставляють у визначеному сценарієм порядку та завантажують на ПлК. Протягом тестування, користувачі можуть лише почергово гортати зображення екранів. Пізніше цей метод удосконалили [11]. На етапі підготовки почали додатково визначати зони взаємодії, що дозволило зменшити детермінованість концептуального прототипу ЕВ для ПлК, але збільшило час його розроблення. Для того, щоб 


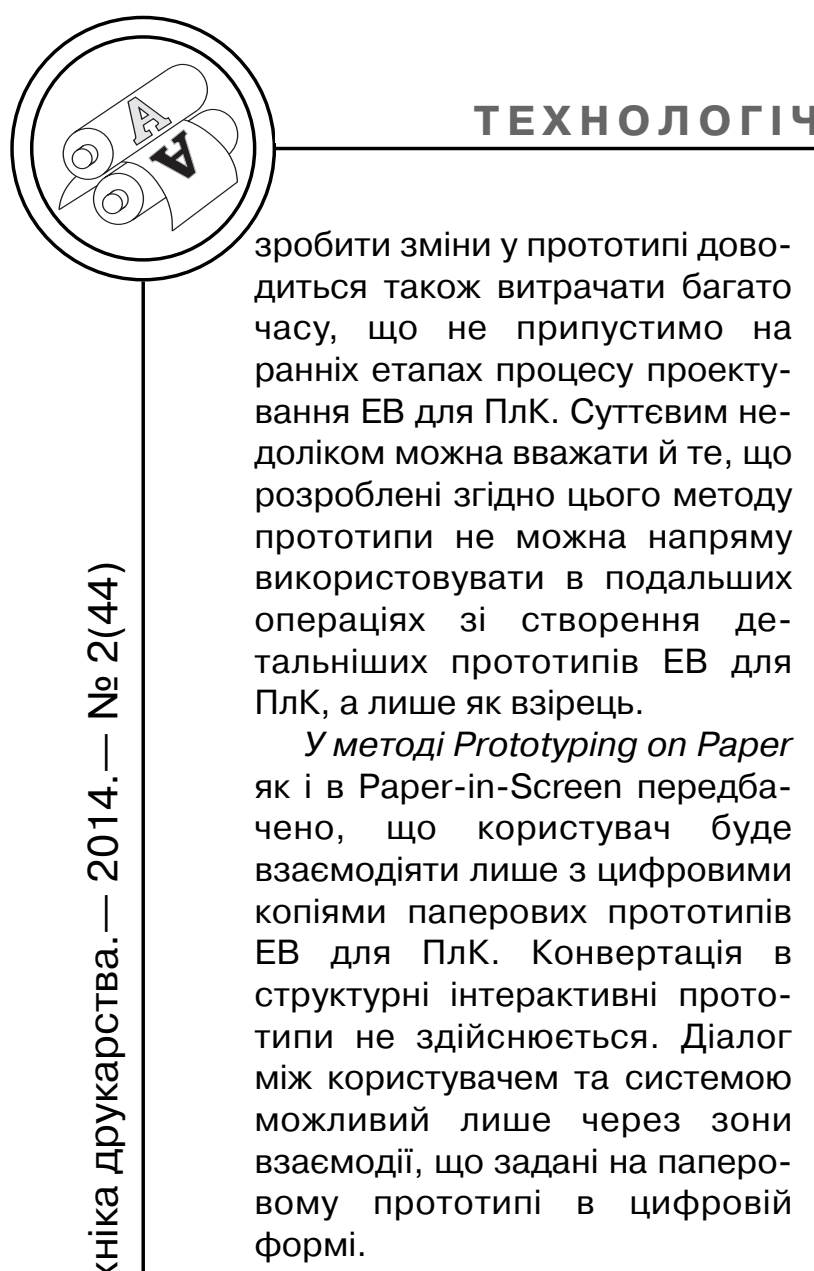

UXPin Notepads - спеціально розроблені блокноти (на даний момент лише для смартфонів і мережевих ресурсів, що будуть використовуватись на ПК). Без них проектувальник не зможе розробити концептуальні прототипи ЕВ для ПлК. Крім того, зони взаємодії задають на комп'ютері перед завантаженням прототипів на ПлК, що сповільнює процес проектування системи. Підхід «Digital Pen» також передбачає, що спеціалісти залучені до проектування ЕВ для ПлК будуть використовувати спеціальну «цифрову ручку» та спеціально підготовлені аркуші, на яких зображатимуть паперові прототипи ЕВ для ПлК. В тому чисті необхідно постійно перебувати біля комп'ютера, що повинен у реальному часі інтерпретувати рухи «цифрової ручки». Крім того, як і в більшості описаних вище підходів проектувальники не зможуть отримати в своє розпорядження структурні прототипи EВ для ПлК. Така можливість не передбачена цим методом.

\section{Мета роботи}

Дослідити існуючі методи створення інтерактивних структурних прототипів системи на основі її паперових зразків. Запропонувати метод розроблення концептуальних прототипів ЕВ для ПлК.

\section{Результати проведених досліджень}

Створюваний метод розроблення концептуальних прототипів EВ для ПлК повинен мати ряд відмінностей та переваг порівняно з відомими способами. Основна ідея, яку слід покласти в його основу - проста й швидка трансформація паперових прототипів у структурні інтерактивні прототипи ЕВ для ПлК з допомогою АСП концептуальних прототипів ЕВ для ПлК. На основі прототипів, що утворилися в результаті роботи АСП, користувачі здатні оцінити придатність до використання системи на ПлК у реальних умовах. Це означає, що користувач матиме можливість взаємодіяти 3 інтерактивним прототипом ЕВ за межами випробувальної лабораторії й на конкретному мобільному пристрої. В деяких випадках потрібно мати можливість отримані прототипи передавати на стадію розроблення ЕВ для ПлК як готову частину системи (наприклад, гене- 
рується HTML і CSS код). Розроблення інтерактивних прототипів системи на ранніх етапах потребує набагато більше зусиль, аніж створення паперових прототипів, тому АСП концептуальних прототипів призначена для того, щоб ефективно вирішити цю задачу.

Як уже зазначалося вище, достатній набір прототипів необхідний для того, щоб забезпечити процес розроблення ЕВ для ПлК повинен містити концептуальні прототипи системи. Перелік дій, який необхідно для цього виконати становить четвертий рівень ієрархічної структури інформаційної технології проектування ЕВ для ПлК. Водночас перелік цих функцій (див. рис. 1) стане основою пропонованого нижче методу розроблення концептуальних прототипів ЕВ для ПлК.

Дія А531. Протягом цієї дії керівник проекту зі створення ЕВ для ПлК дає команди й визначає умови виконання дій усієї операції.

Дія А532. Протягом цієї дії група, залучених до проектування спеціалістів, розробляє паперові прототипи ЕВ для ПлК й розкадровки (англ. storyboard, послідовність паперових прототипів, що описує поведінку користувача ЕВ для ПлК). При цьому вони слідують такій послідовності кроків (технології розроблення концептуальних прототипів ЕВ для ПлК).

Етап 1. Підготовчий. На папері друкують або з допомогою штампа наносять зображення фронтальної частини ПлК (шаблон), для яких проектують ЕВ. Таких зображень-шаблонів мо- же бути декілька. Це залежить від діагоналі й співвідношення сторін дисплея ПлК. Кожен аркуш повинен мати унікальну нумерацію. Площа на папері, що відповідає дисплею ПлК має містити міліметрову сітку, що зумовлено необхідністю зображати реальні розміри об'єктів інтерфейсу EB для ПлК. Наприклад, 3 мм - мінімальний розмір візуальних цільових зон для ПлК з діагоналлю 910 дюймів; розміри цільових зон дотику: 6 мм - мінімальний, 8 мм - рекомендований, 15 мм максимальний; відстань між сусідніми цільовими об'єктами по центрах: 8 мм - мінімальна, 10 мм - рекомендована [12]. У більшості випадків, зображати всю фронтальну частину ПлК немає потреби, можна обмежитися лише зоною дисплея 3 сіткою. Для цього необхідно виділити її на папері суцільною лінією. Також необхідно підготувати лінійки, трафарети з елементами інтерфейсу ЕВ для ПлК, олівці (в тому числі кольорові), кольоровий папір, інше канцелярське приладдя.

Етап 2. Накреслити вміст екранів EB для ПлК. За допомогою звичайного олівця під лінійку або від руки чи 3 допомогою трафарету креслять прямокутники, пунктирні або суцільні лінії яких проходять через точки міліметрової сітки. Кожен такий чотирикутник зображає якийсь елемент інтерфейсу. Наприклад, текстовий блок позначають написом «текст» або трьома, розташованими один під одним, паралельними лініями усередині прямокутника; прямокутник з двома 


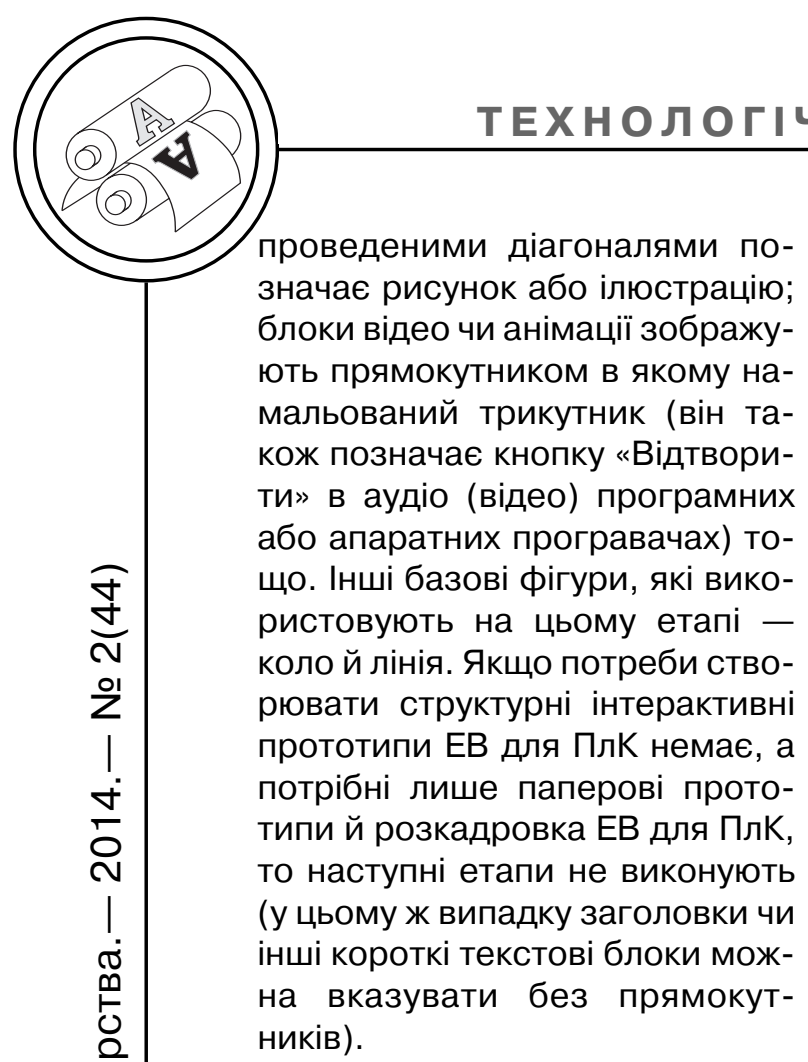

Етап 3. Визначити зони взаємодії. Протягом цього етапу позначають інтерактивні об'єкти на паперових прототипах. На одному аркуші не повинно бути більше семи зон взаємодії. Така їх кількість зумовлена обмеженими можливостями короткочасної пам'яті людини. Позначають цільові зони дотику з допомогою семи кольорів райдуги, що розміщені в послідовності зменшення довжини світлової хвилі. Червоний колір - це перша зона взаємодії, оранжевий - друга, жовтий - третя, зелений - четверта, блакитний - п'ята, синій - шоста, фіолетовий сьома. На практиці це реалізують наступним чином. У визначеному місці аркуша прикладають або приклеюють (на липкій основі) папірець прямокутної форми потрібного розміру й кольору. Також прямокутну інтерактивну площину можна окреслити пунктирними або суцільними лініями відповідного кольору. Якщо візуальна цільова зона співпадає з цільовою зоною дотику, то їх зображають пунктирною чи суцільною лінію потрібного кольору. Зауважимо, що тип лінії в подальшому вплине на результат роботи АСП концептуальних прототипів ЕВ для ПлК. Пунктирна лінія не буде відображатися на інтерактивному структурному прототипі (на відміну від суцільної), вона призначена для того, щоб визначати розмір вміщеної в її межах цільової зони дотику. Це зауваження також властиве другому етапу. Пунктирна лінія не буде відображатися (на відміну від суцільної), але визначатиме, наприклад, кегель шрифту чи розмір іншого об'єкта.

Етап 4. Задати для зон взаємодії пари дія-результат. Це завершальний етап у підготовці паперових прототипів до опрацювання їх у АСП концептуальних прототипів EB для ПлК. У результаті його реалізації проектувальники формують таблицю 3 чотирма стовпцями. Кількість рядків змінна й залежить від анотованого опису поведінки користувача, що передбачена в розкадровці ЕВ для ПлК. Отож, у першому стовпці вказують номер аркуша паперового прототипу ЕВ для ПлК. У другому - колір зони взаємодії (лише першу букву, наприклад, замість слова «зелений» вказують «з»). У третьому - число, що відповідає певній дії користувача ЕВ для ПлК. Це жести для взаємодії з сенсорним дисплеєм, наприклад, 1 дотик (англ. tap), 2 - подвійний дотик (англ. double tap), 3 - до- 
тик і утримання (англ. long press), 4 - протягування для прокручування (англ. scroll), 5 зведення чи розведення для масштабування (англ. pinch close \& pinch open), 6 - протягування для переміщення (англ. pan), 7 - повертання (англ. rotate) тощо. У четвертому стовпці вказують номер аркуша, на який переходить користувач або номер елемента EB, що повинен з'явитися на екрані ПлК (результат взаємодії користувача).

Дія А533. Протягом цієї дії проектувальники використовують АСП концептуальних прототипів для того, щоб перетворити паперові прототипи й розкадровки ЕВ для ПлК у структурні інтерактивні прототипи. 3 цією метою в АСП роблять фотознімки аркушів за допомогою камери, що вбудована в ПлК. Після цього АСП автоматично (на основі запрограмованих алгоритмів) опрацьовує фотографії. Одна з основних ідей, що покладена в роботу АСП - технологія розширеної реальності (англ. augmented reality). Це інтелектуальне середовище, що утворене в результаті поєднання об'єктів реального світу з даними, що згенеровано на комп'ютері. АСП може розпізнати матеріальні об'єкти зовнішнього світу (такі як кольоровий папір) та перетворити їх у віртуальні інтерактивні зони; пронумеровані папірці певної форми визначати як елемент інтерфейсу з множиною заданих властивостей (попередньо необхідно в параметрах АСП числам призначити певний елемент). Окрім цього з допомогою
АСП можна виконати оптичне розпізнавання символів і подальше їх редагування. Таким чином, у результаті функціонування АСП фахівці отримують структурні прототипи ЕВ для ПлК, яким характерні низька точність і базова інтерактивність. Пізніше їх передають спеціалістам, які за участі зацікавлених сторін здійснюють оцінку придатності до використання, а саме: обговорюють альтернативні проектні рішення, визначають можливість реалізації концептуальних прототипів EВ для ПлК. За умови, що розробляти проміжні й детальні прототипи ЕВ для ПлК немає потреби спеціалісти, що розробляють проектну документацію починають виконувати наступну дію A534, в протилежному випадку переходять до операції A54.

Дія А534. Протягом цієї дії група фахівців, залучених до проектування EВ для ПлК, здійснює оформленням необхідної документації для забезпечення процесу розроблення ЕВ для ПлК. Додаткову описову інформацію можуть створювати лише для паперових прототипів ЕВ для ПлК, якщо за результатами їх оцінювання прийнято рішення про те, що розробляти структурні інтерактивні прототипи EB для ПлК немає потреби.

Керівник проекту зі створення ЕВ для ПлК виробляє команди й умови виконання дій (A532, А533, А534), а також приймає рішення (дія А531) про перехід від виконання однієї функції до іншої (черговість реалізації дій А532, А533, А534) 


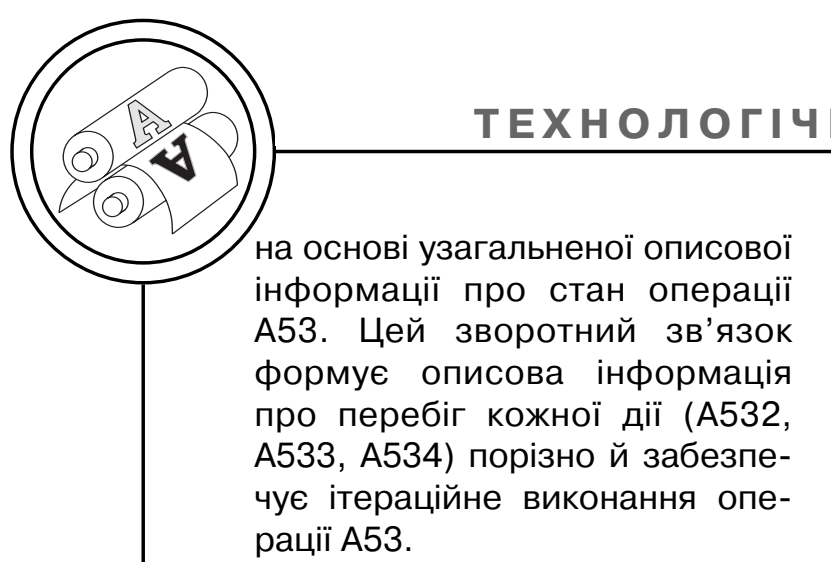

Звичайно, пропонований у роботі метод має ряд потенційних недоліків. По-перше, редагувати у спеціалізованому програмному забезпеченні вміст прототипів, що зображають екрани ЕВ для ПлК простіше, аніж олівцем на папері. По-друге, велика ймовірність появи помилок розпізнавання текстової та графічної інформації. Повний перелік проблемних моментів дозволить виявити лише всебічне тестування розробленої АСП концептуальних прототипів ЕВ для ПлК. Проте, запропонований метод розроблення концептуальних прототипів ЕВ для ПлК можна легко й швидко реалізувати на практиці. Він не потребує від проектувальників спеціальних знань або навичок програмування. Навпаки, описаний метод - простий і доступний для спеціалістів-гуманітаріїв, які зазвичай здатні створити зрозумілий інтерфейс користувача ЕВ для ПлК (англ. natural user interface) [13] на відміну від технічно орієнтованих фахівців. Приклад, в якому застосовують запропонований метод розроблення концептуальних прототипів ЕВ для ПлК зображено на рис. 2. Зауважимо, що наведений приклад показує лише дії А532, А533, а також результати ї виконання.
Важливою складовою запропонованого методу трансформації паперових прототипів ЕВ для ПлК у базові структурні інтерактивні прототипи ЕВ для ПлК є АСП концептуальних прототипів ЕВ для ПлК. Один з макетів іiі інтерфейсу зображено на рис. 3.

Проектувальники використовуватимуть АСП на ПлК, що належать до різних мобільних апаратно-програмних платформ (МАПП). Тому АСП потрібно розробити для кожної з них. Наприклад, веб-програму можна реалізувати на основі відкритих технологій, а саме: HTML, CSS, JavaScript тощо [14]. Власну програму для МАПП Android зазвичай розробляють за наявності таких інструментів: інтегрованого середовища розроблення (англ. IDE - Integrated Development Environment) Eclipse (з додатковим програмним модулем (англ. Plug-in) ADT - Android Development Tools), середовища Java (JDK - Java Development Kit i JRE - Java Runtime Environment), набору засобів для розроблення програмного забезпечення (англ. SDK - Software Development (Developer's) Kit) Android [15]. На практиці використовують набагато ширший набір апаратно-програмних засобів [16] для розроблення власних програм для МААП Android. Набір інструментів потрібний для розроблення АСП у вигляді власної програми для MAПП IOS охоплюе такі компоненти: персональні комп'ютери Apple Мас з операційною системою OS X, середовище Xcode IDE 3 структурою Cocoa Touch та інші 


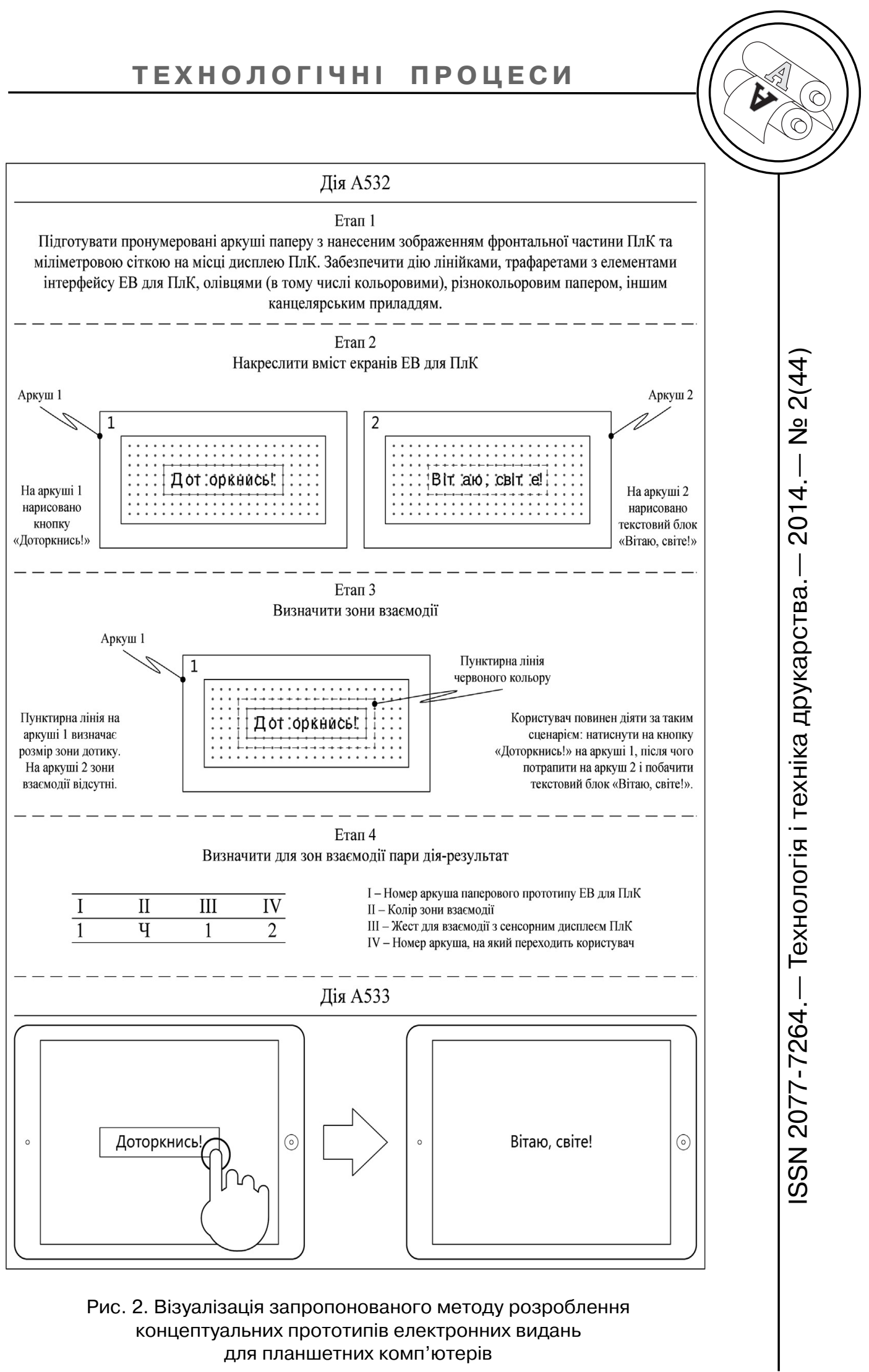




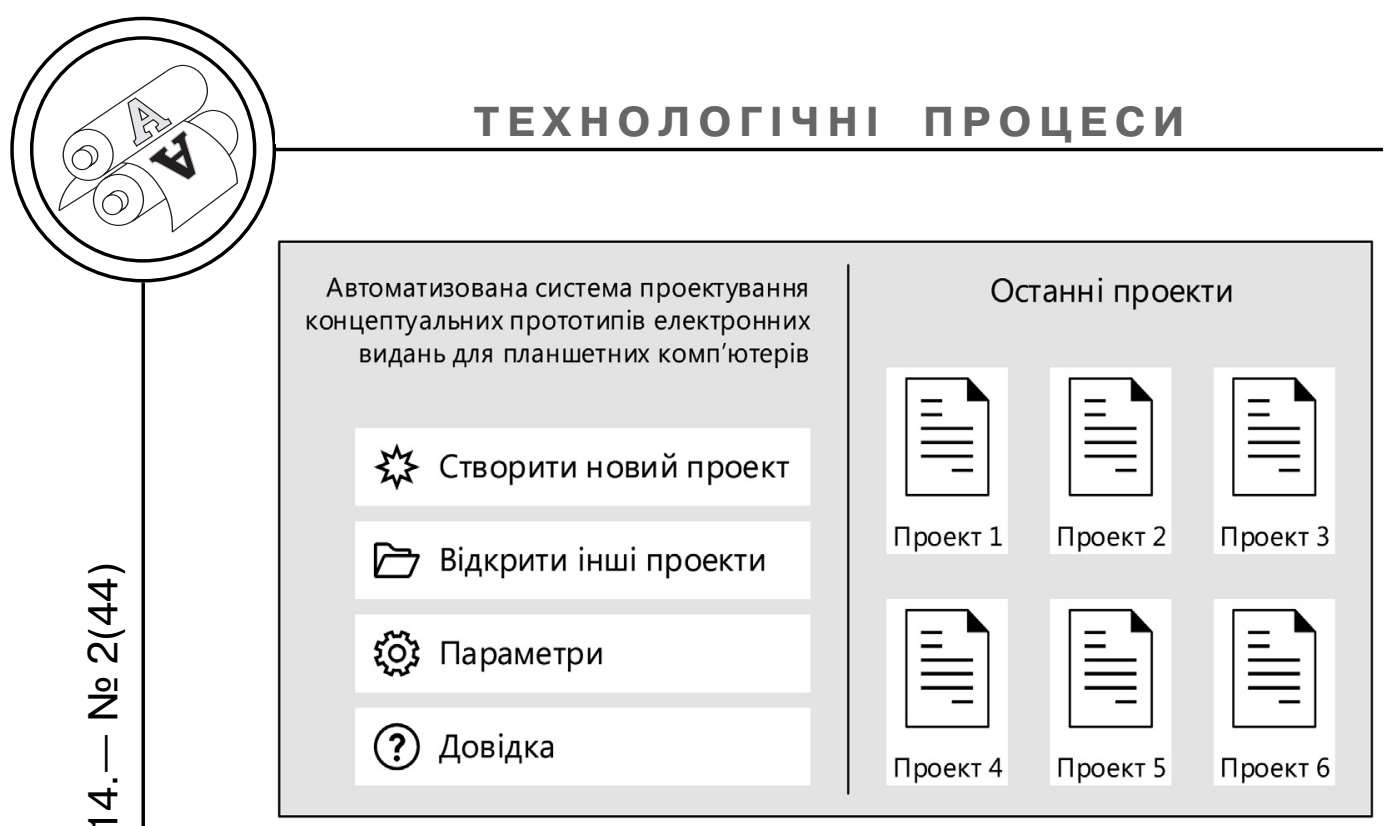

Рис. 3. Макет інтерфейсу початкового екрана АСП концептуальних прототипів електронних видань для планшетних комп'ютерів

[17]. Для створення власної програми для МАПП Windows використовують Windows SDK. Зауважимо, що АСП - це кросплатформний програмний продукт, для розроблення якого можна також використовувати відповідні засоби й методи [18].

Як уже зазначалося вище, АСП призначена для запуску на ПлК, а тому їі інтерфейс обов'язково повинен бути адаптованим для керування пальцями рук. Одразу після дотику до піктограми АСП перед проектувальником ЕВ для ПлК з'являється екран, зображений на рис. 3. Умовно він розділений вертикальною лінією на дві зони. Ліворуч для користувача доступні такі пункти основного меню: створити новий проект, відкрити інші проекти, параметри й довідка. Праворуч представлені проекти, з якими нещодавно взаємодіяв користувач АСП концептуальних прототипів EВ для ПлК. Розглянемо еле- менти інтерфейсу детальніше. Після того, як користувач АСП натискає кнопку меню «Створити новий проект», він потрапляє до основного робочого екрана АСП, де потрібно робити фотографії паперових прототипів ЕВ для ПлК. Пункт меню «Відкрити інші проекти" використовують у тому випадку, якщо в списку «Останні проекти» відсутній необхідний проект. Активація пункту основного меню «Параметри» перенесе проектувальника до екрана, що містить властивості АСП, які можна змінити. Нарешті 3 додатковою інформацією про можливості АСП та настановами з використання цієї системи можна ознайомитися після дотику до пункту меню «Довідка».

\section{Висновки}

Проаналізовано найбільш відомі способи отримання інтерактивних структурних прототипів системи на основі її паперових зразків. Запропоно- 
вано метод розроблення концептуальних прототипів EВ для ПлК і показано його місце у структурі інформаційної технології проектування ЕВ для ПлК. Визначено перелік потенційних недоліків пропонованої АСП. Наведено приклад застосування запропонованого методу (показано дії A532, A533, а також результати їх виконання). Названо апаратно-програмне забезпечення (інструментарій), потрібне для розроблення АСП концептуальних прототипів ЕВ для ПлК. Створено макет інтер- фейсу початкового екрана АСП і розглянуто його компоненти.

Актуальним продовження проведеного дослідження вважаємо розроблення АСП концептуальних прототипів ЕВ для ПлК. На початковому етапі вирішення поставленої задачі необхідно провести моделювання програмної системи на основі об'єктно-орієнтованої методології (наприклад, використовувати уніфіковану мову моделювання UML - Unified Modeling Language) [19].

\section{Список використаної літератури}

1. Ратушняк Ю. В. Функціональна модель процесу проектування електронних видання для планшетних комп'ютерів / Ю. В. Ратушняк // Поліграфія і видавнича справа. - 2013. - № 12(6162). - С. 41-51.

2. Ратушняк Ю. В. Структура інформаційної технології проектування електронних видань для планшетних комп'ютерів / Ю. В. Ратушняк // Texнологія і техніка друкарства. - 2014. - № 1(43). - С. 55-67.

3. Hartson R. The UX Book : Process and guidelines for ensuring a quality user experience / R. Hartson, P. Pyla. - NY: Morgan Kaufmann, 2012. - 968 p.

4. Bolchini D. Feature : «Paper in screen» prototyping : an agile technique to anticipate the mobile experience / D. Bolchini, D. Pulido, A. Faiola // ACM interactions, XVI.4, July/August 2009. - P. 29-33.

5. POP - Prototyping on paper [Електронний ресурс]. - Режим доступу : https://popapp.in/.

6. UXPin paper prototyping notepads [Електронний ресурс]. - Режим доступу : http://uxpin.com/products.html.

7. Holzmann C. Building interactive prototypes of mobile user interfaces with a digital pen / C. Holzmann, M. Vogler // APCHI'12, August 2821, 2012, Matsuecity, Shimane, Japen. - P. 159-168.

8. Wilson P. Active story : a low fidelity prototyping and distributed usability testing tool for agile teams. University of Calgary, MSc thesis, August 2008.

9. Landay J. Interactive sketching for the early stages of user interface design. PhD thesis, Carnegie Mellon University, 1996.

10. Lin J. A visual language for sketching large and complex interactive designs / J. Lin, M. Thomsen, J. Landay // In proceedings of the SIGCHI conference on Human factors in computing systems: Changing our world, changing ourselves, ACM (2002), P. 307-314.

11. Davies T. Designing with paper prototyping [Електронний ресурс]. Режим доступу : http://www.uxbooth.com/articles/paper-prototyping/.

12. Hoober S. Common misconceptions about touch [Електронний pecypc]. - Режим доступу : http://www.uxmatters.com/mt/archives/2013/ 03/common-misconceptions-about-touch.php.

13. Hinman R. The mobile frontier : a guide for designing mobile experiences / R. Hinman. - NY : Rosenfeld Media, 2012. - 264 p. 


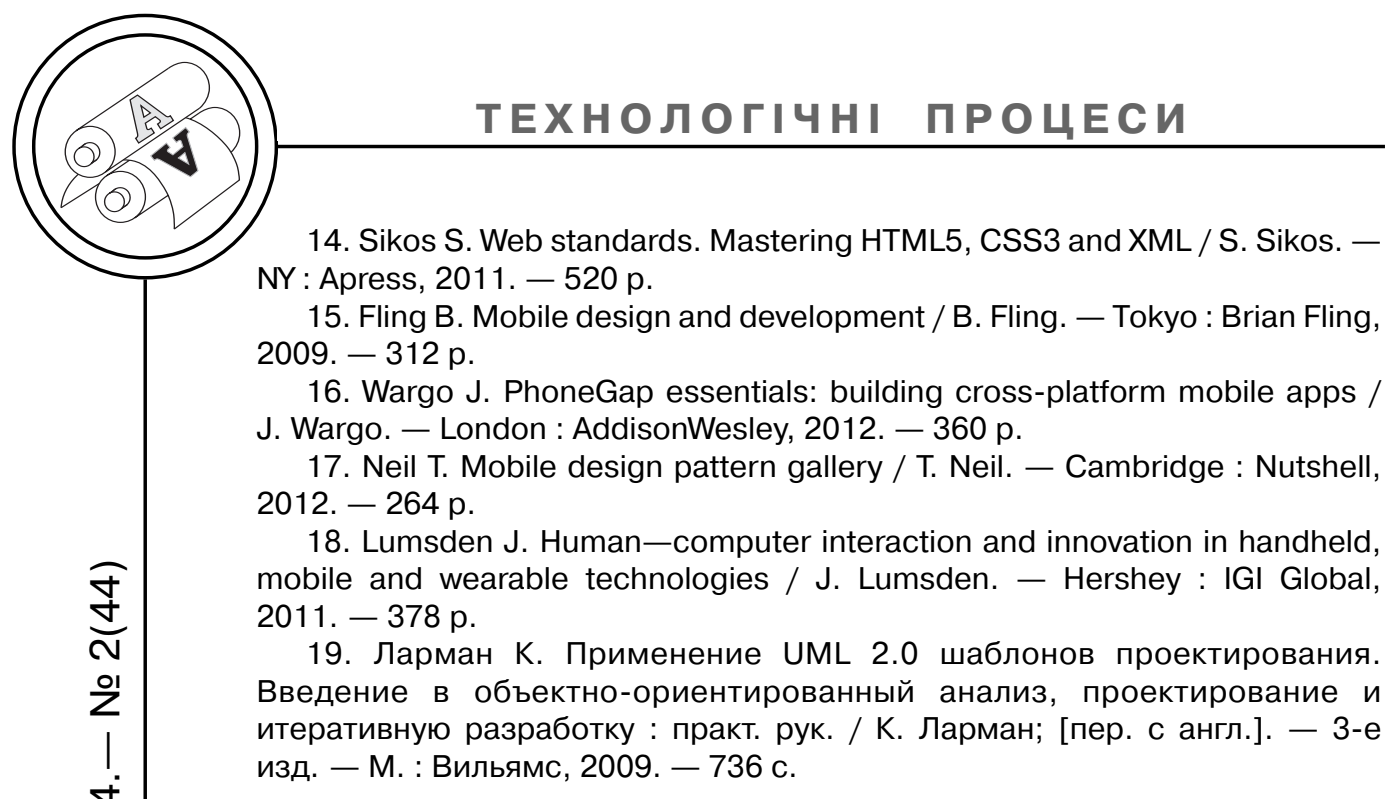

\section{References}

1. Ratushniak lu. V. Funktsionalna model protsesu proektuvannia elektronnykh vydannia dlia planshetnykh komp'iuteriv / lu. V. Ratushniak // Polihrafiia i vydavnycha sprava. - 2013. - № $12(6162)$. - S. 41-51.

2. Ratushniak lu. V. Struktura informatsiinoi tekhnolohii proektuvannia elektronnykh vydan dlia planshetnykh komp'iuteriv / lu. V. Ratushniak // Tekhnolohiia i tekhnika drukarstva. - 2014. - № 1(43). - S. 55-67.

3. Hartson R. The UX Book: Process and guidelines for ensuring a quality user experience / R. Hartson, P. Pyla. - NY: Morgan Kaufmann, 2012. - 968 p.

4. Bolchini D. Feature : «Paper in screen» prototyping : an agile technique to anticipate the mobile experience / D. Bolchini, D. Pulido, A. Faiola // ACM interactions, XVI.4, July/August 2009. - P. 29-33.

5. POP - Prototyping on paper [Elektronnyi resurs]. - Rezhym dostupu : https://popapp.in/.

6. UXPin paper prototyping notepads [Elektronnyi resurs]. - Rezhym dostupu : http://uxpin.com/products.html.

7. Holzmann C. Building interactive prototypes of mobile user interfaces with a digital pen / C. Holzmann, M. Vogler // APCHI'12, August 2821, 2012, Matsuecity, Shimane, Japen. - P. 159-168.

8. Wilson P. Active story : a low fidelity prototyping and distributed usability testing tool for agile teams. University of Calgary, MSc thesis, August 2008.

9. Landay J. Interactive sketching for the early stages of user interface design. PhD thesis, Carnegie Mellon University, 1996.

10. Lin J. A visual language for sketching large and complex interactive designs / J. Lin, M. Thomsen, J. Landay // In proceedings of the SIGCHI conference on Human factors in computing systems: Changing our world, changing ourselves, ACM (2002), P. 307-314.

11. Davies T. Designing with paper prototyping [Elektronnyi resurs]. Rezhym dostupu : http://www.uxbooth.com/articles/paper-prototyping/.

12. Hoober S. Common misconceptions about touch [Elektronnyi resurs]. Rezhym dostupu : http://www.uxmatters.com/mt/archives/2013/03/commonmisconceptions-about-touch.php.

13. Hinman R. The mobile frontier : a guide for designing mobile experiences / R. Hinman. - NY : Rosenfeld Media, 2012. - 264 p.

14. Sikos S. Web standards. Mastering HTML5, CSS3 and XML / S. Sikos. NY : Apress, 2011. - 520 p. 
15. Fling B. Mobile design and development / B. Fling. - Tokyo : Brian Fling, 2009. - $312 \mathrm{p}$.

16. Wargo J. PhoneGap essentials: building cross-platform mobile apps / J. Wargo. - London : AddisonWesley, 2012. - 360 p.

17. Neil T. Mobile design pattern gallery / T. Neil. - Cambridge : Nutshell, 2012. -264 p.

18. Lumsden J. Human-computer interaction and innovation in handheld, mobile and wearable technologies / J. Lumsden. - Hershey : IGI Global, 2011. - $378 \mathrm{p}$.

19. Larman K. Primenenie UML 2.0 shablonov proektirovanija. Vvedenie v objektno-orientirovannyj analiz, proektirovanie i iterativnuju razrabotku : prakt. ruk. / K. Larman; [per. s angl.]. - 3-e izd. - M. : Vil'jams, 2009. - 736 s.

В процессе проектирования электронных изданий для планшетных компьютеров используют разнообразные методы и аппаратно-программные средства разработки прототипов. Исследование и создание новых эффективных методов получения концептуальных прототипов электронных изданий для планшетных компьютеров является актуальной и целесообразной задачей. В работе ее удалось решить с использованием методов системного анализа. Таким образом, проанализированы наиболее известные способы получения интерактивных структурных прототипов системы на основе ее бумажных образцов. Предложен метод разработки концептуальных прототипов и указано его место в структуре информационной технологии проектирования электронных изданий для планшетных компьютеров. Определен перечень потенциальных недостатков предлагаемой автоматизированной системы проектирования. Приведен пример применения предложенного метода. Приведен перечень аппаратно-программное обеспечение, необходимого для разработки автоматизированной системы проектирования концептуальных прототипов электронных изданий для планшетных компьютеров. Создан макет интерфейса начального экрана автоматизированной системы проектирования и рассмотрены его компоненты.

Ключевые слова: автоматизированная система проектирования; электронное издание; интерфейс; информационная технология; концептуальный прототип; метод; планшетный компьютер; проектирование; разработка.

Designers use different methods, hardware and software for prototypes development in the process of designing the electronic editions for tablet computers. The urgent and appropriate task is the new effective development methods of conceptual prototypes of electronic editions for tablet computers research and creation. This paper provides task solution using systems analysis methods. The known conversion methods of system 
paper prototypes to its interactive wireframes have been analyzed. The development method of conceptual prototypes has been proposed and its place in the information technology structure of designing the electronic editions for tablet computers has been shown. The list of proposed CAD system potential shortcomings has been defined. The example of the proposed method application has been shown. The hardware and software list needed to develop the CAD system of conceptual prototypes of electronic editions for tablet computers has been defined. The prototype of start screen interface of CAD system has been developed and its components have been described.

Keywords: CAD system; electronic edition; interface; information technology; conceptual prototype; method; tablet computer; design; development.

Рецензент - О. В. Зоренко, к.Т.н., доцент, НТУУ «КП।

Надійшла до редакції 10.04.14 